\title{
From Embryo to Adult: Persistent Neurogenesis and Apoptotic Cell Death Shape the Lobster Deutocerebrum
}

\author{
Steffen Harzsch, ${ }^{1}$ Julie Miller, ${ }^{2}$ Jeannie Benton, ${ }^{2}$ and Barbara Beltz ${ }^{2}$ \\ 1 Universität Bielefeld, Fakultät für Biologie, Neuroanatomie, 33615 Bielefeld, Germany, and 'Wellesley College, \\ Department of Biological Sciences, Wellesley, Massachusetts 02481-8283
}

\begin{abstract}
Neuronal plasticity and synaptic remodeling play important roles during the development of the invertebrate nervous system. In addition, structural neuroplasticity as a result of longterm environmental changes, behavioral modifications, age, and experience have been demonstrated in the brains of sexually mature insects. In adult vertebrates, persistent neurogenesis is found in the granule cell layer of the mammalian hippocampus and the subventricular zone, as well as in the telencephalon of songbirds, indicating that persistent neurogenesis, which is presumably related to plasticity and learning, may be an integral part of the normal biology of the mature brain. In decapod crustaceans, persistent neurogenesis among olfactory projection neurons is a common principle that shapes the adult brain, indicating a remarkable degree of life-long structural plasticity. The present study closes a gap in our knowledge of this phenomenon by describing the continuous cell proliferation and gradual displacement of proliferation domains in the central olfactory pathway of the American lobster Homarus americanus from early embryonic through larval and juvenile stages into adult life. Neurogenesis in the deutocere-
\end{abstract}

brum was examined by the in vivo incorporation of bromodeoxyuridine, and development and structural maturation of the deutocerebral neuropils were studied using immunohistochemistry against Drosophila synapsin. The role of apoptotic cell death in shaping the developing deutocerebrum was studied using the terminal deoxynucleotidyl transferase-mediated biotinylated UTP nick end labeling method, combined with immunolabeling using an antiphospho histone H3 mitosis marker. Our results indicate that, in juvenile and adult lobsters, birth and death of olfactory interneurons occur in parallel, suggesting a turnover of these cells. When the persistent neurogenesis and concurrent death of interneurons in the central olfactory pathway of the crustacean brain are taken into account with the life-long turnover of olfactory receptor cells in crustacean antennules, a new, highly dynamic picture of olfaction in crustaceans emerges.

Key words: Crustacea; Homarus americanus; deutocerebrum; plasticity; neurogenesis; BrdU; phosphorylated histone H3; apoptosis; TUNEL; synapsin
Murphey's (1986) striking paper The Myth of the Inflexible Invertebrate was among the first contributions highlighting the role of neuronal plasticity and synaptic remodeling during development of the invertebrate nervous system. Since then, numerous studies have provided evidence for developmental plasticity in invertebrates as diverse as molluscs (Bulloch and Jones, 1988; Marois and Carew, 1990; Hickmott and Carew, 1991), the leech (Macagno et al., 1990; French and Kristan, 1994; Wolszon, 1995), and insects (Truman, 1992; Levine et al., 1995; Keshishian et al., 1996; Weeks and Wood, 1996). Processes of structural plasticity have also been reported from the adult invertebrate nervous system (Technau, 1984; Bulloch and Ridgway, 1989; Withers et al., 1993, 1995; Fahrbach et al., 1995a; Heisenberg et al., 1995; Gronenberg et al., 1996; Winnington et al., 1996; Sigg et al., 1997). Moreover, increasing evidence suggests that persistent neurogenesis related

\footnotetext{
Received Dec. 17, 1998; revised Feb. 11, 1999; accepted Feb. 17, 1999.

This study was supported by Deutsche Forschungsgemeinschaft Grant Ha 2540/ 1-2 and National Science Foundation Grant IBN 9709514. We thank E. Buchner for kindly providing antibodies and the Brandeis Biology Department for access to their confocal microscopy facility. We are indebted to J. Goldstein from the Lobster Rearing and Research Facility at the New England Aquarium (Boston, MA), M. Syslo from the Massachusetts State Lobster Hatchery (Martha's Vineyard, MA) for providing egg-bearing lobsters, and P. Carey and V. Quinan for technical assistance. Our special thanks go to M. Schmidt, R. E. Sandeman, and D. C. Sandeman for their stimulating criticism on this manuscript and G. Teuchert-Noodt and R. R. Dawirs for discussion.

Correspondence should be addressed to Dr. Barbara Beltz, Wellesley College, Department of Biological Sciences, Wellesley, MA 02481-8283.

Copyright (C) 1999 Society for Neuroscience $0270-6474 / 99 / 193472-14 \$ 05.00 / 0$
}

to plasticity and learning may be an integral part of the normal adult brain biology in vertebrates (Alvarez-Buylla and Temple, 1998; Cameron and McKay, 1998).

In the CNS of decapod crustaceans, persistent neurogenesis within a cluster of deutocerebral interneurons has been reported to take place in juvenile (Harzsch and Dawirs, 1996) and adult (Schmidt, 1997) animals of two crab species. A further comparative analysis has led to the conclusion that persistent neurogenesis among olfactory projection neurons is a common principle of the adult brain of decapod crustaceans, indicating an unexpected degree of life-long structural plasticity (Harzsch and Schmidt, 1996; Schmidt and Harzsch, 1999). An interesting implication of these reports is that the age of the crustaceans studied exceeds the age of all insects examined (Bieber and Fuldner, 1979; Technau and Heisenberg, 1982; Cayre et al., 1994, 1996) and matches or exceeds the age of most birds and rodents in which persistent neurogenesis has been found in the adult brain (Alvarez-Buylla and Temple, 1998; Cameron and McKay, 1998). A turnover of receptor neurons and lesion-induced neuronal plasticity recently have been reported from the crayfish olfactory pathway (Sandeman and Sandeman, 1996; Sandeman et al., 1998). However, the temporal dynamics of persistent neurogenesis in the olfactory pathway of crustaceans and the ontogenetic origin of the adult proliferation domains (PDs) are as yet poorly understood.

To address these questions, we monitored neurogenesis [in vivo incorporation of bromodeoxyuridine $(\mathrm{BrdU})]$ in the deutocere- 

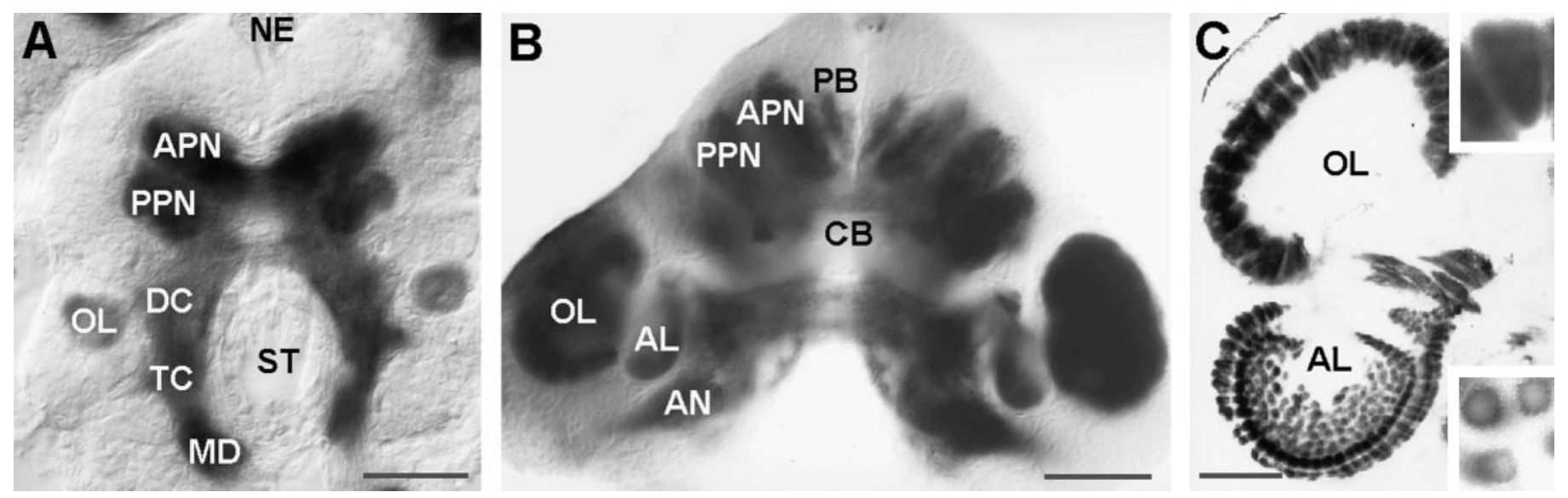

Figure 1. Immunohistochemical detection of Drosophila synapsin (SYNORF1) in the lobster brain to show the structural maturation of the deutocerebral neuropils. $A, \mathrm{E} 25 \%$, whole mount, the olfactory lobe has formed. $B, \mathrm{E} 70 \%$, whole mount, olfactory and accessory lobes are present. $C$, Adult, 7-year-old, vibratome section; conical glomeruli have formed in the olfactory lobe (top inset), whereas the accessory lobe is composed of spherical glomeruli (bottom inset). $A L$, Accessory lobe; $A N$, antenna 2 neuropil; $A P N$, anterior protocerebral neuropil; $C B$, central body; $D C$, deutocerebral neuropil anlage; $M D$, neuropilanlage of the anterior mandibular neuromere; $N E$, naupliar eye; $O L$, olfactory lobe; $P B$, protocerebral bridge; $P P N$, posterior protocerebral neuropil; $S T$, stomodaeum; $T C$, tritocerebral neuropil anlage. Scale bars: $A, B, 100 \mu \mathrm{m} ; C, 200 \mu \mathrm{m}$.

brum of the American lobster Homarus americanus from early embryonic stages onward through larval and juvenile life (to $0.5 \mathrm{~kg}$; $\sim 7$ years old) adult animals. Development and structural maturation of the deutocerebral neuropils were examined using immunohistochemistry against Drosophila synapsin. The role of apoptotic cell death in shaping the developing deutocerebrum was studied using the in situ terminal deoxynucleotidyl transferase-mediated biotinylated UTP nick end labeling (TUNEL) method. Our results indicate that, in juvenile and adult lobsters, birth and death of olfactory interneurons occur in parallel, suggesting a turnover of these interneurons in mature crustacean brains.

\section{MATERIALS AND METHODS}

Animals. Ovigerous female lobsters Homarus americanus (Decapoda, Homarida, Nephropidae), larvae, and juveniles were obtained from the lobster rearing and research facility at the New England Aquarium (Boston, MA) and the Massachusetts State Lobster Hatchery (Martha's Vineyard, MA) and kept in recirculating artificial seawater at $18^{\circ} \mathrm{C}$. Embryos were staged according to Helluy and Beltz (1991) on the basis of length and width of the pigmented zone in the eye. Larvae and juveniles were reared according to Helluy et al. (1995) and Harzsch et al. (1998) and staged according to Charmantier et al. (1991). Adult lobsters (to $0.5 \mathrm{~kg} ; \sim 7$ years old) were obtained from the Bay State Lobster Company (Boston, MA). For the present study, animals from 25 to $100 \%$ embryonic development (E25\%-E100\%), postembryonic stages 1-4, stage 7 juveniles, 0.5 - and 1.5-year-old juveniles, and 7-year-old adult lobsters were processed and analyzed.

BrdU labeling. Proliferation of cells was monitored by in vivo labeling with BrdU (Dolbeare, 1996). Embryos and larvae were exposed to BrdU (Cell Proliferation kit RPN 20; Amersham, Little Chalfont, Buckinghamshire, UK) diluted in seawater to a concentration of $0.2 \mathrm{mg} / \mathrm{ml}$ for 4 $\mathrm{hr}$ at $18^{\circ} \mathrm{C}$. This $4 \mathrm{hr}$ time span has been found to provide a strong labeling of cycling cells while the number of labeled cells is still low enough to be analyzed efficiently (Harzsch and Dawirs, 1994). In juvenile and adult lobsters, BrdU was injected into the ventral hemolymph sinus of the pleon at a concentration of $3 \mathrm{mg}$ of BrdU/100 gm body weight twice in $24 \mathrm{hr}$. The animals were then cooled on ice, and the brain was dissected and fixed in $4 \%$ paraformaldehyde in $0.1 \mathrm{M}$ phosphate buffer, $\mathrm{pH}$ 7.4, for $1 \mathrm{hr}$ (embryos and larvae) or overnight (juveniles and adults). To determine the fate of the newly born cells, 7-year-old adult animals were injected with BrdU and killed after a survival time of 6 weeks (pulse-chase experiments). In addition, juvenile animals were labeled with a first pulse of BrdU 3 weeks before being killed and with a second pulse on the day the animals were killed to determine the spatial relationship of the 3 -week-old cells and the present proliferation domain. Whole mounts of the brain (embryos and larvae) or $70-100 \mu \mathrm{m}$ vi- bratome sections (juveniles and adults) were processed immunohistochemically as described by Harzsch and Dawirs (1994). Specimens were incubated for $2.5 \mathrm{hr}$ in a primary anti-BrdU mouse antibody (1:100; Cell Proliferation kit RPN 20; Amersham) and afterward for $1 \mathrm{hr}$ in a peroxidase-coupled secondary goat anti-mouse antibody (1:70). The signal was developed with diaminobenzidine. The brains were drawn using a camera lucida device, and the number of labeled cells was counted.

TUNEL and double labeling to detect proliferating and dying cells. In situ TUNEL (Ben-Sasson et al., 1995; Sanders and Wride, 1996; Harzsch et al., 1999) was performed to detect cells that undergo apoptotic cell death (Kerr et al., 1995; White, 1996; Jacobson et al., 1997) using the In situ Cell Death Detection kit by Boehringer Mannheim (Mannheim, Germany). Dissected brains were fixed for $4 \mathrm{hr}$ in $4 \%$ paraformaldehyde in 0.1 M phosphate buffer, $\mathrm{pH} 7.4$, at room temperature. Whole mounts of the brain (embryos) or $70 \mu \mathrm{m}$ vibratome sections (adults) were washed in several changes of PBS $(0.1 \mathrm{M}), \mathrm{pH} 7.4$, for $1 \mathrm{hr}$ and then incubated for $15 \mathrm{~min}$ in Proteinase K (25 $\mu \mathrm{g}$ in $1 \mathrm{ml}$ of PBS; Sigma, St. Louis, MO) at room temperature (Negoescu et al., 1996). After washing in PBS for another hour, specimens were processed with the Boehringer Mannheim kit according to the manufacturer's instructions and finally mounted in glycerol. To perform negative controls, specimens were incubated in the nucleotide mixture label solution alone, and the terminal deoxynucleotidyl enzyme solution was omitted. Mounted specimens (glycerol) were viewed with a fluorescence microscope (Microphot-FXA; Nikon, Tokyo, Japan) or a Bio-Rad (Hercules, CA) 600 confocal laser scanning microscope equipped with a krypton-argon gas laser and standard BHS filter. The Comos software package by Bio-Rad was used for collecting images. Images were processed using Photoshop (Adobe Systems, San Jose, CA).

To examine the spatial relationship of dying and proliferating cells, a double-labeling procedure was devised using the Boehringer Mannheim TUNEL kit and the antiphospho histone $\mathrm{H} 3$ mitosis marker (phos H3; Upstate Biotechnology, Lake Placid, NY). Phosphorylation of histone H3 occurs during M-phase when the chromosomes are fully condensed (Gurley et al., 1978; Ajiro et al., 1996). After pretreatment with Proteinase $\mathrm{K}$, specimens were incubated overnight $\left(4^{\circ} \mathrm{C}\right)$ in the antiphospho histone $\mathrm{H} 3$ primary antibody (rabbit polyclonal $\mathrm{IgG}$ ) at a dilution of 1:200 in PBS plus $0.3 \%$ Triton $\mathrm{T} X-100,5 \%$ normal goat serum, and $0.015 \%$ sodium azide (PBS-TX). After washing in PBS for $1 \mathrm{hr}$, specimens were incubated for $2 \mathrm{hr}\left(37^{\circ} \mathrm{C}\right)$ in the TUNEL reaction mixture (fluorescein-conjugated). After another wash in PBS (1 hr), specimens were incubated in an anti-rabbit Texas Red-conjugated secondary antibody (1:50 in PBS; Molecular Probes, Cambridge, MA), washed in PBS, and mounted in glycerol.

Immunohistochemistry against Drosophila synapsin. Dissected brains were fixed for $4 \mathrm{hr}$ in $4 \%$ paraformaldehyde in $0.1 \mathrm{M}$ phosphate buffer, $\mathrm{pH}$ 7.4 , at room temperature. Whole mounts of the brain (embryos) or $70 \mu \mathrm{m}$ 

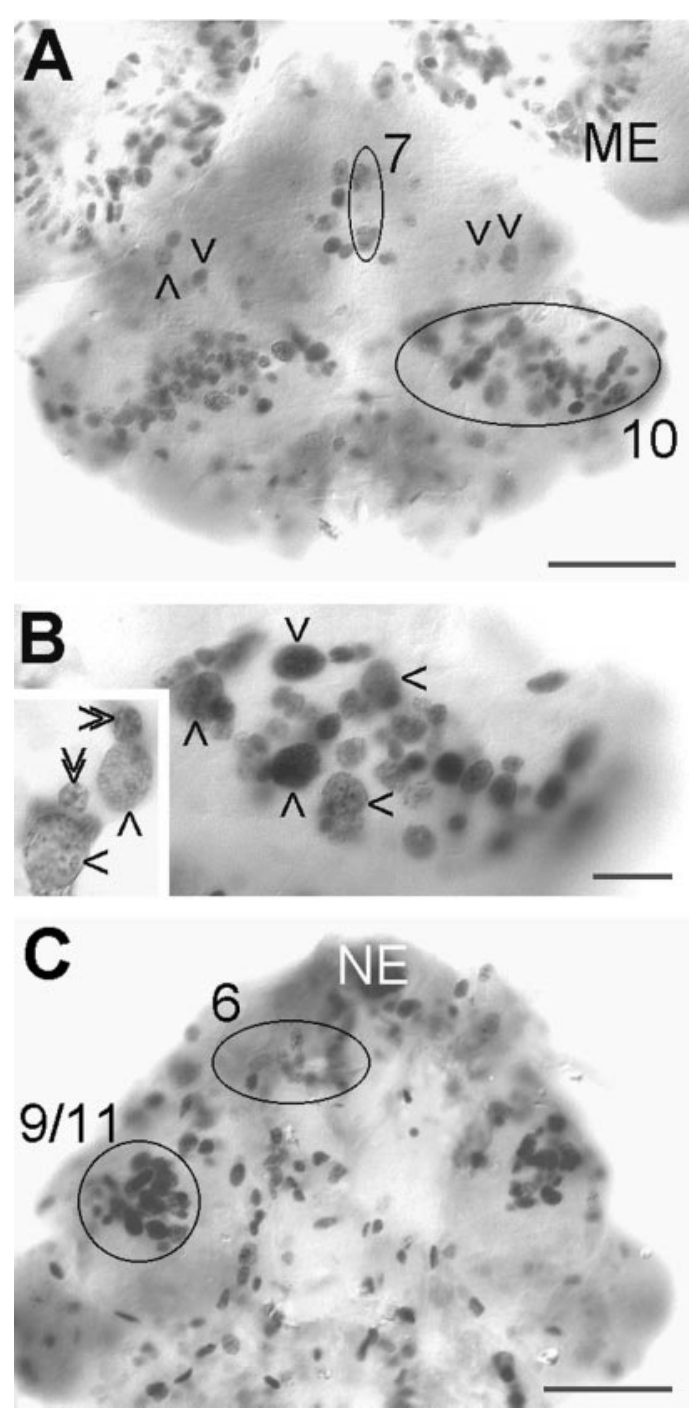

Figure 2. Neurogenesis in the embryonic lobster brain, whole mounts of brains at E25\%, $4 \mathrm{hr}$ pulse of BrdU. A, Ventral aspect showing PDs 7 and 10 (circles), single scattered neuroblasts (arrowheads), and the proliferation zone of the medulla externa $(M E)$ in the eye disc. $B$, Higher magnification of PD 10 with several labeled neuroblasts (arrows). Inset, Higher magnification of neuroblasts (single arrowheads) and associated progeny, the ganglion mother cells (double arrowheads). C, Dorsal aspect showing PDs 9/11 and 6 (circles, the contralateral PD 6 is distorted and out of focus) and location of naupliar eye (NE). Scale bars: $A, C, 100 \mu \mathrm{m} ; B, 25 \mu \mathrm{m}$.

vibratome sections (adults) were processed immunohistochemically as described by Harzsch et al. (1997). Incubation in the anti-synapsin SYNORF1 antibody [1:30 in PBS-TX (Klagges et al., 1996); antibody provided by E. Buchner, Universität Würzburg, Germany] was performed overnight at $4^{\circ} \mathrm{C}$. Specificity controls included the omission of the

Figure 3. Structure and location of the persisting proliferation domains (shaded dark gray) in the embryonic (E25\% and E70\%) and adult lobster brain. Arrows in E70\% show the direction of growth of the OL and AL and subsequent relocation of PDs 10 and 9/11. Light gray areas surrounding PDs 10 and 9/11 designate the extension of cell clusters 10 and 9/11, which contain the somata of mature olfactory interneurons. The neuritic morphologies of local (cluster 9) and projection (cluster 10) interneurons are shown on the right half of the figure. A1, $A 2$, Antenna 1 and 2 nerves; $A L$, accessory lobe; $A N$, antenna 2 neuropil; $A P N$, anterior protocerebral neuropil; $C B$, central body; $C O N$, connective; $L A N$, lateral antenna 1 neuropil; $M A N$, median antenna 1 neuropil; $M D$, neuropil anlage of the
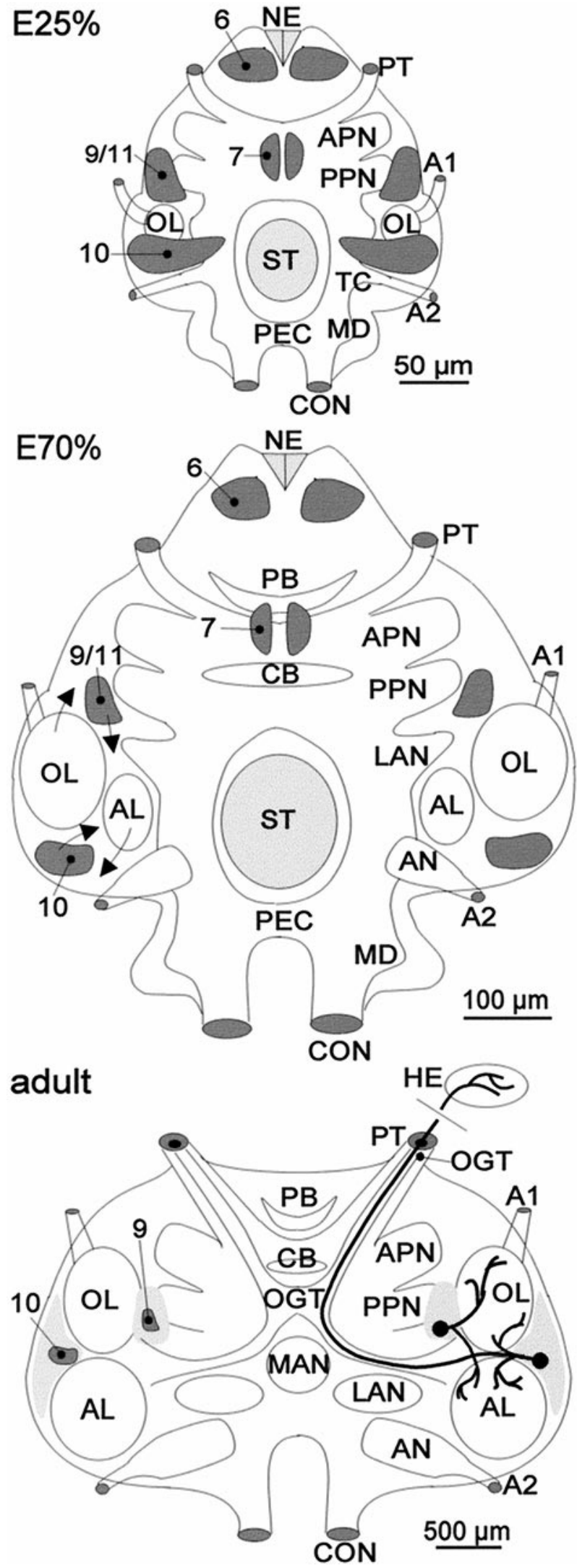

anterior part of the mandibular neuromere; $N E$, naupliar eye; $O L$, olfactory lobe; $P B$, protocerebral bridge; $P E C$, postesophageal commissure; $P P N$, posterior protocerebral neuropil; $P T$, protocerebral tract; $S T$, stomodaeum; $T C$, tritocerebral neuropil anlage; $6,7,10,9 / 11$, proliferation domains $6,7,10$, and 9/11. 

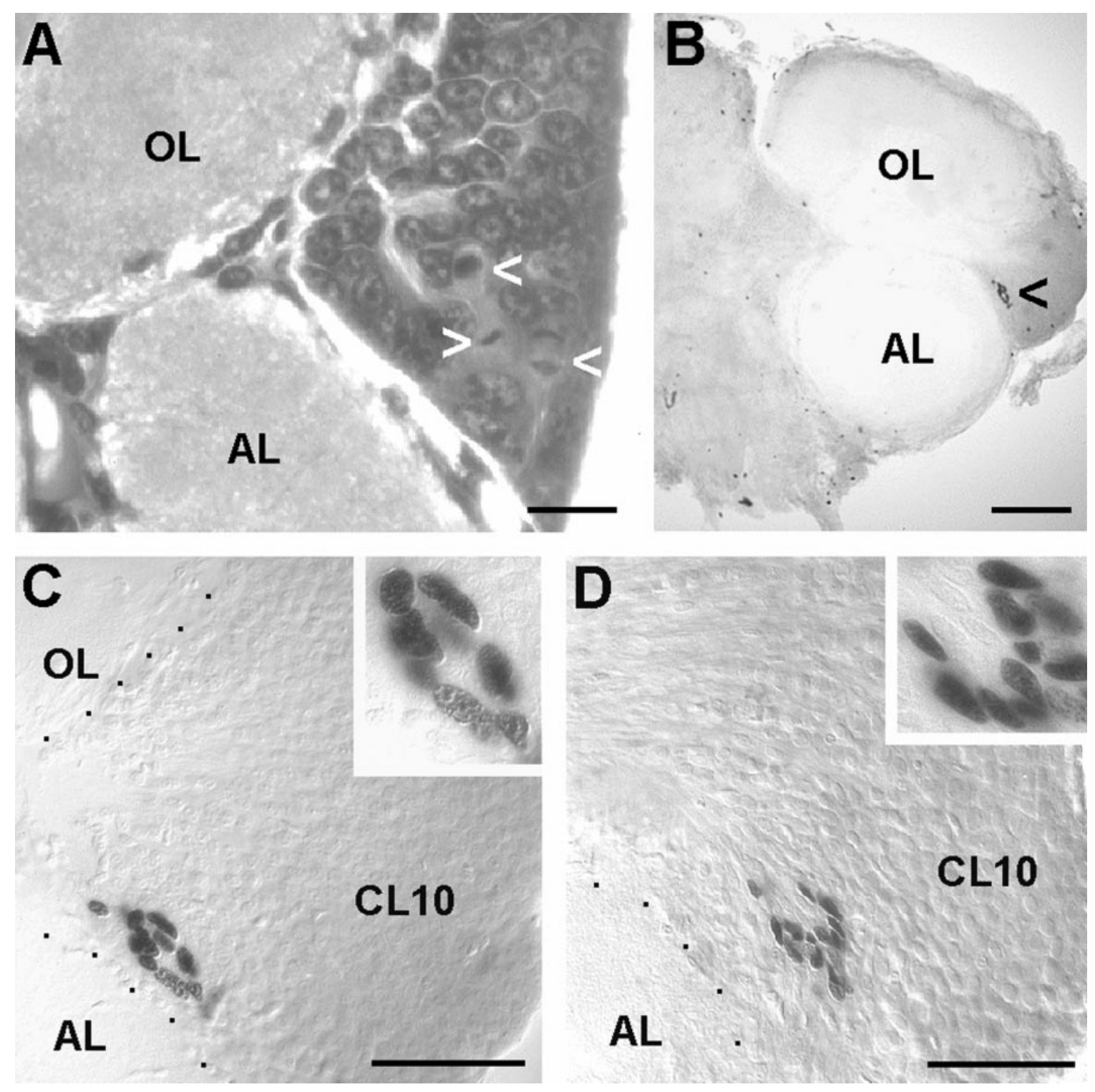

Figure 4. Persistent cell proliferation in cell cluster 10 (containing olfactory projection neurons) of the olfactory brain of larval, juvenile, and adult lobsters. $A$, Toluidine blue-stained section, stage 4 larva; arrowheads, PD 10, cells in M-phase. $B-D$, Vibratome sections, two BrdU injections in 24 hr; $B, C$, Juvenile, 1.5 -year-old, labeled nuclei in PD 10 (arrowhead in $B) ; D$, Adult, 7-year-old, labeled nuclei in PD. $A L$, Accessory lobe; $C L 10$, cell cluster 10; $O L$, olfactory lobe. Scale bars: $A, 20 \mu \mathrm{m} ; B, 100 \mu \mathrm{m} ; C, D, 50 \mu \mathrm{m}$.

primary antibodies, in which case neuronal staining was completely absent.

Histology. Toluidine blue-stained serial sections $(3-7 \mu \mathrm{m})$ of plastic (JB-4)-embedded brains were examined to determine the position of mitotic and pyknotic cells in the deutocerebrum of embryos and larvae. This material was prepared as described by Helluy et al. (1995) and was available for the present study.

\section{RESULTS}

\section{Development of the deutocerebral neuropils}

Immunohistochemistry with the anti-Drosophila synapsin antibody SYNORF1 results in intense staining of the neuropil. In an embryo at E25\%, the characteristic subdivision of the crustacean brain into protocerebrum (anterior and posterior motocerebral neuropils), deutocerebrum and tritocerebrum are evident (Fig. $1 A$ ). These structural features of the developing lobster brain correspond closely with those described previously in crayfish and lobster embryos (Sandeman and Sandeman, 1990; Helluy et al.,
1993; Scholtz, 1995) and larvae of crabs (Harzsch and Dawirs, 1993, 1996). The tritocerebrum is attached caudally to the anterior half of the mandible neuromere (Fig. $1 A, M D$ ), which later becomes the commissural ganglion (Harzsch et al., 1997, 1998). In the deutocerebrum, a distinct anlage of the olfactory lobe $(\mathrm{OL})$ is evident at E25\%. At E70\% (Fig. 1B), the size of the OL has increased substantially, and a second deutocerebral neuropil, the accessory lobe (AL), has appeared medial to the OL. During successive development, there are further changes in the morphology of the deutocerebrum. The AL is displaced to a position posterior to the OL (Helluy et al., 1995) (Fig. 1C). Structural refinement of the neuropil results in the formation of characteristic conical glomeruli in the cortex of the OL during midembryonic life and the postembryonic formation of spherical glomeruli in the cortex of the AL (Helluy et al., 1996) (Fig. 1C). 

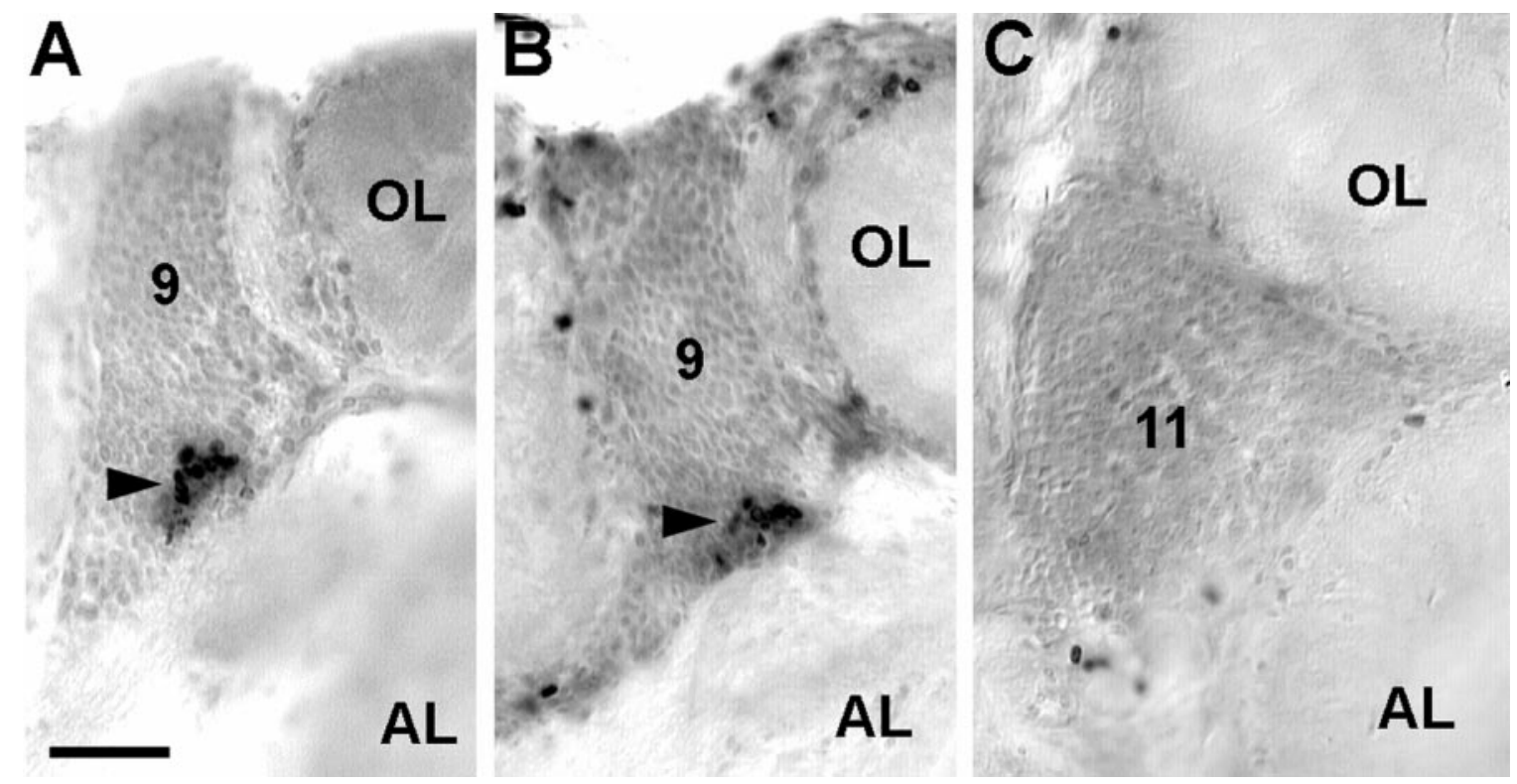

Figure 5. Persistent cell proliferation is also found in the medial cell cluster 9 of the brain but not in cluster 11 (both clusters contain local olfactory interneurons). $A-C$, Juvenile, 0.5 -year-old, series of vibratome sections. $A$ and $B$ show the proliferation domain (arrowhead) in successive sections of the ventrally located cluster 9. $C$ shows a section of the dorsally located cluster 11 of the same animal. $A L$, Accessory lobe; 9, cell cluster 9; 11 , cell cluster 11; $O L$, olfactory lobe. Scale bar: $A-C, 50 \mu \mathrm{m}$.

\section{Proliferation of neuronal precursors}

In the embryonic brain, in vivo incorporation of BrdU and subsequent immunohistochemical detection results in numerous tightly packed groups of black-stained cell nuclei, which are arranged superficially in the emerging cell clusters (Fig. 2). Four major groups of labeled cells (PDs) can be distinguished (Fig. 2): PD 6 contributes progeny to cell cluster 6 , the anterior medial cells (Sandeman et al., 1992, their nomenclature); PD 7 contributes progeny to cluster 7, the ventral anterior cells; PD 9/11 contributes progeny to cluster $9 / 11$, the ventral and dorsal medial cells (it was not possible from our material to distinguish these two clusters in embryos); and PD 10 contributes progeny to cluster 10 , containing the olfactory projection neurons. In these PDs, large labeled nuclei of neuroblasts (Nbs) can be distinguished from the smaller labeled nuclei of their associated progeny, the ganglion mother cells (Fig. $2 B$, inset). Because of the high numbers of Nbs in the PDs, they were not identified individually. Neuroblasts of malacostracan crustaceans undergo unequal divisions to produce ganglion mother cells, which later divide again to give birth to ganglion cells (Dohle, 1976; Scholtz, 1992; Harzsch and Dawirs, 1994, 1996; Gerberding, 1997; Harzsch et al., 1998, 1999; for review, see Whitington, 1996; Dohle and Scholtz, 1997; Dohle, 1997). Apart from the Nbs in the PDs, single Nbs also are scattered on the surface of the brain (Fig. $2 A$ ).

In the embryonic brain, PD 10 is located ventrally and stretches laterally from near the midline to partly wrap around the developing OL in a dorsolateral direction (Fig. $2 A, B$ ). PD 9/11 is located anteriorly to the OL and stretches from the dorsal surface deep into the brain, almost reaching the ventral surface of the tissue (Fig. 2C). During subsequent development, PDs 10 and
9/11 are displaced because of the expansion of the OL and AL (Fig. 3). The OL expands in an anterolateral direction, thereby pushing PD 9/11 in a medial direction. The expanding AL is displaced in a posterolateral direction so that PD 10 becomes embedded within the ventral portion of cell cluster 10 in a position between the AL and OL (Figs. 3, 4). Continuous cell proliferation within and gradual displacement of these PDs were confirmed throughout larval development into juvenile and adult stages. In postembryonic stages, no more large labeled neuroblast-like cells could be found, but the BrdU-labeled cells in PD 10 all seemed to be of uniform size and shape (Fig. 4C,D, insets). In addition to BrdU labeling, the presence of dividing cells in PD 10 was confirmed by the analysis of toluidine blue-stained histological sections (Fig. 4A). In larval, juvenile, and adult brains labeled with BrdU, PDs 9 and 10 show the most obvious signs of ongoing cell proliferation in the central part of the brain. Apart from these PDs, there are only a few scattered BrdU labeled cells, and it is unclear whether these are neuronal or glial cells (Fig. $4 B)$. BrdU labeled cells were regularly found in cluster 9/11 throughout embryonic and larval stages. In 0.5-year-old juvenile animals, we were able to determine the location of this proliferation domain more exactly because of the growth of the brain, which allows a better separation of cell clusters 9 and 11. In these animals, the proliferation domain is clearly restricted to ventral cell cluster 9, whereas the dorsal cluster 11 is devoid of mitotic cells (Fig. 5).

Pulse-chase experiments in 7-year-old adults revealed that, 6 weeks after BrdU incorporation, the labeled cells have dispersed and have been pushed anteriorly toward the center of cluster 10 (Fig. 6A,B). The vast majority of the labeled nuclei has obtained

Figure 6. Pulse-chase experiments with 7-year-old adults to examine the fate of cells that were born in cluster 10 during adulthood. $A, B$, Six weeks after the BrdU injection, the labeled cells have dispersed within cluster 10. $C, F$, The vast majority of the labeled nuclei have obtained a shape and size that is indistinguishable from that of the surrounding interneurons in cluster 10, suggesting that most of the newly born cells in the adult deutocerebrum have differentiated into neurons. $G$, The shape and size of occasionally labeled glial nuclei (arrow) is clearly different from (Figure legend continues) 

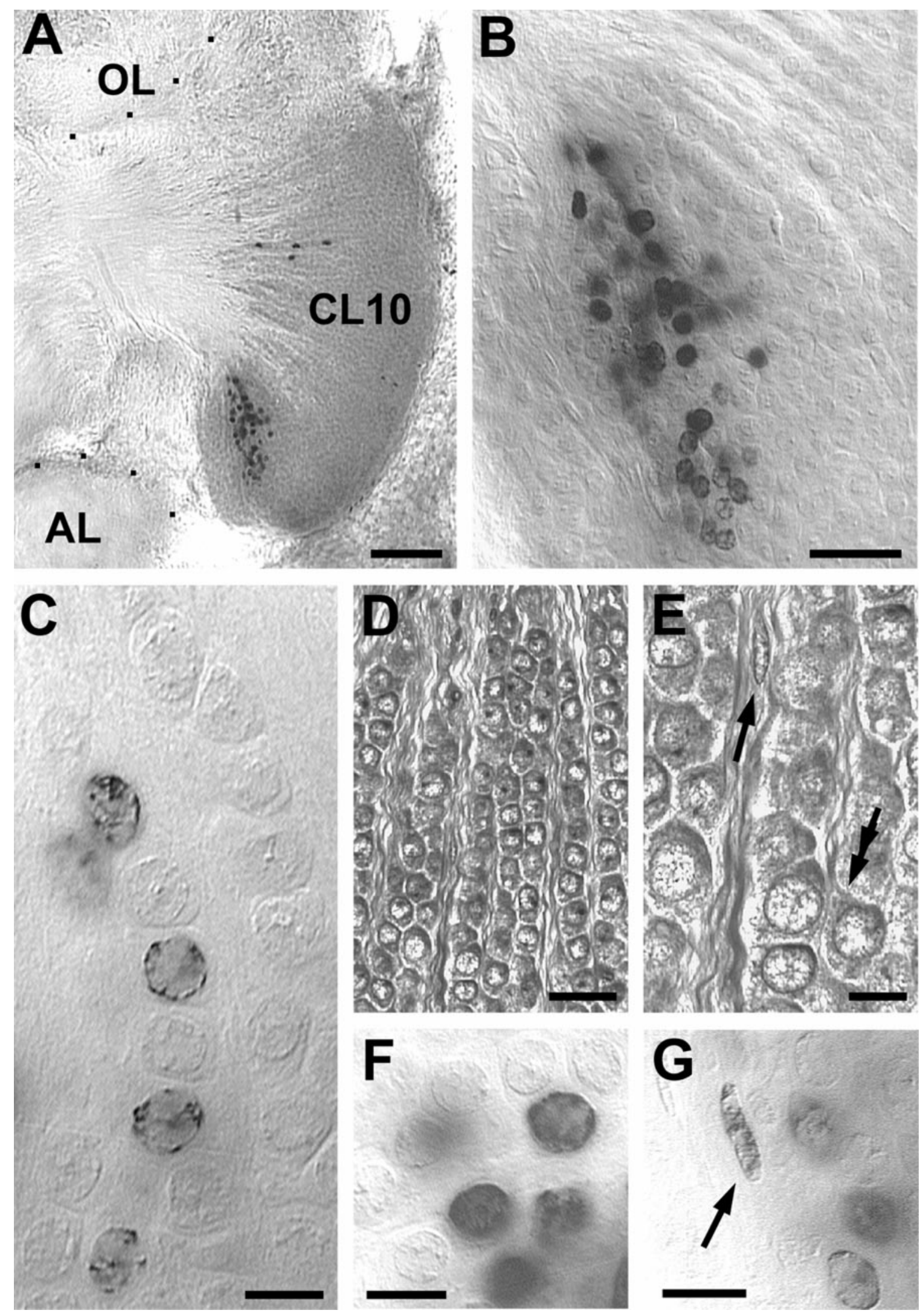

that of the labeled neurons $(F)$. $C$, The newly born neurons often are arranged in a string-like pattern. $D, E$, Toluidine blue-stained histological sections of the adult brain show that the interneurons in cluster 10 are organized in rows that are separated by bundles of their axons (double arrow in $E$ points to neurite emerging from a neuron). The histological sections also reveal that, in the adult brain, cluster 10 is almost exclusively composed of neuronal cell bodies. Very few of the typically spindle-shaped glial cells can be found in cluster 10 and are mostly located along tracts of neurites (arrow in $E$ ). $A L$, Accessory lobe; $O L$, olfactory lobe; $C L 10$, cell cluster 10 . Scale bars: $A, 50 \mu \mathrm{m} ; B, D, 20 \mu \mathrm{m} ; C, E-G, 5 \mu \mathrm{m}$. 

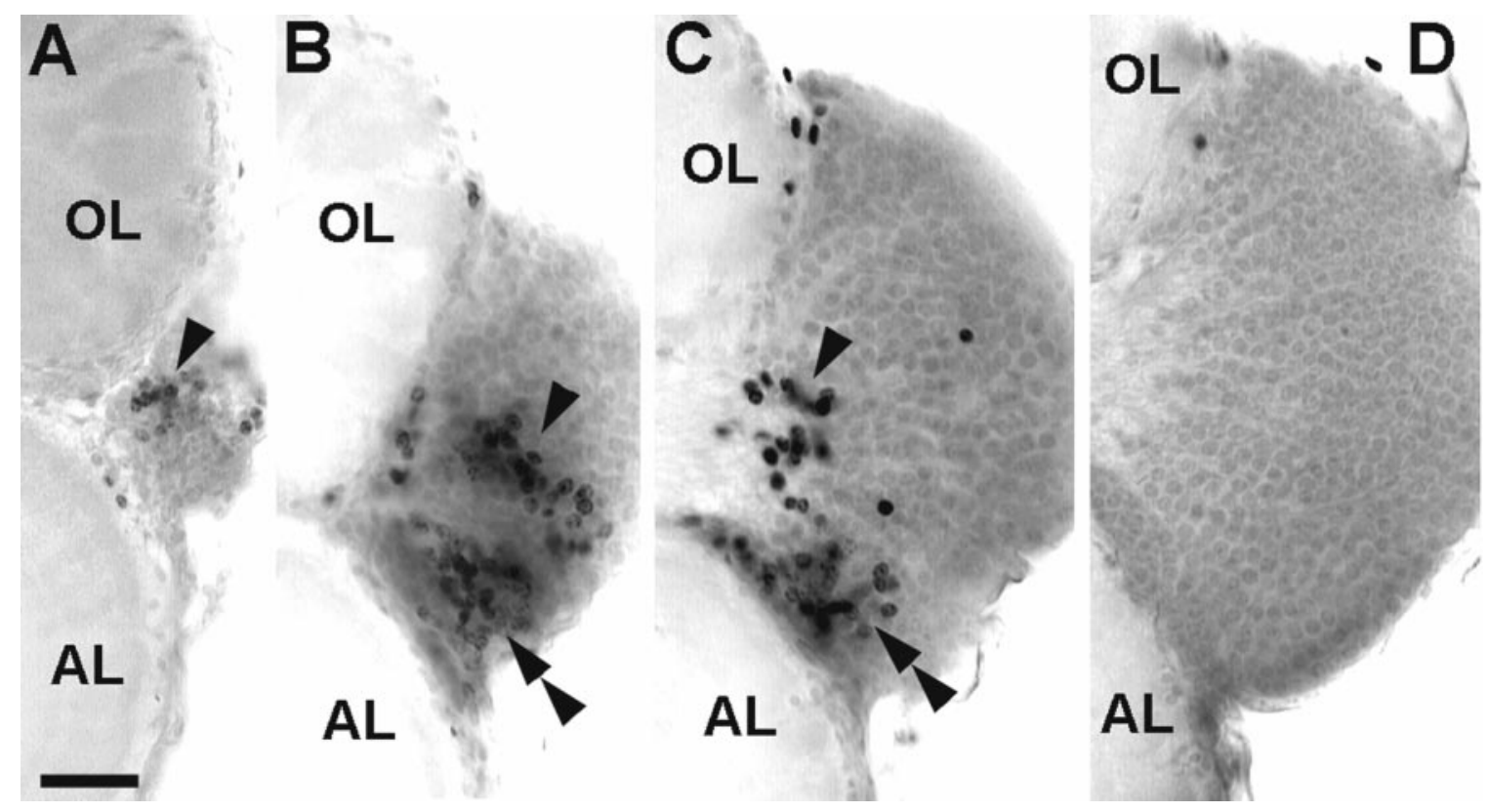

Figure 7. Pulse-chase experiments with 0.5-year-old juveniles to examine the fate of the newly born cells in cluster 10. Animals were labeled with a first pulse of BrdU 3 weeks before being killed and with a second pulse on the day they were killed. $A-D$, Series of successive $100 \mu \mathrm{m}$ vibratome sections of a single brain starting ventral $(A)$ and proceeding dorsally. Single arrowheads point to the cluster of neurons labeled during the first BrdU pulse. Double arrowheads point to the cluster of cells that were labeled by the second pulse immediately before the animals were killed. $A L$, Accessory lobe; $O L$, olfactory lobe. Scale bar: $A-D, 50 \mu \mathrm{m}$.

a shape and size that is indistinguishable from that of the surrounding interneurons in cluster 10, suggesting that most of these newly born cells in the adult deutocerebrum have differentiated into neurons (Fig. $6 C-F$ ). The shape and size of occasionally labeled glial nuclei in the pulse chase specimens is clearly different from that of the labeled neurons (Fig. $6 F, G$ ). The newly born neurons often are arranged in a linear pattern (Fig. 6C). Analysis of toluidine blue-stained histological sections of the adult brain revealed that the interneurons in cluster 10 are organized in rows that are separated by bundles of their axons (Fig. 6D,E). The new neurons form rows that are added to the posterior margin of cluster 10 . The histological sections also revealed that, in the adult brain, cluster 10 is almost exclusively composed of neuronal cell bodies (Fig. 6D,E). Only very few of the typically spindle-shaped glial cells can be found and are located mostly along tracts of neurites (Fig. 6E).

In further pulse-chase experiments with 0.5-year-old juveniles, the animals were labeled with the first pulse of BrdU 3 weeks before being killed and then with the second pulse on the day the animals were killed. Analysis of a series of successive $100 \mu \mathrm{m}$ horizontal vibratome sections of a single brain (Fig. $7 A-D$ ) confirmed that PD 10 is located in the ventral half of cluster 10 . Furthermore, the cluster of neurons that was labeled during the first BrdU pulse has been pushed anteriorly toward the center of cluster 10 but did not markedly move in the dorsoventral plane (Fig. $7 B, C$, single arrowhead). The cells that were labeled by the second pulse immediately before the animals were killed (Fig. $7 B, C$, double arrowhead) occupy a posterior position at the margin of cluster 10 close to the AL, hence occupying the typical position of PD 10.

The number of labeled nuclei in the deutocerebral PDs was counted in animals that were labeled by a $4 \mathrm{hr}$ pulse of BrdU. The number of labeled nuclei in both PDs 10 and 9/11 increased from E25\% onward to reach a maximum number of $\sim 100$ between
E50\% and E60\% (Fig. 8A,B). The number of proliferating cells then decreased dramatically toward hatching, and all neurogenic activity in PDs 10 and 9/11 ceased by E90\%. However, neurogenesis resumed after hatching. In larval stages 1-3, 100 cells were labeled per PD 10, whereas the number was lower in PD 9/11 (Fig. $8 C)$. The number of labeled cells decreased after stage 3 in both PDs. The numbers of proliferating cells in the 1.5- and 7-year-old animals are not directly comparable with the former data because a different procedure of BrdU application was used (two BrdU injections in $24 \mathrm{hr}$ ). However, significant numbers of PD 10 cells incorporate BrdU in these older stages (Fig. 8C). Counts for cluster 9 of juvenile and adult animals are not plotted in Figure $8 C$ because we did not generate enough data for a statistical analysis in these stages.

\section{Detection of cell death}

Figure $9 A$ shows a whole mount of an embryonic brain (E25\%) that was processed with the TUNEL assay to detect cells that undergo apoptotic cell death. Numerous TUNEL profiles are scattered in the protocerebrum. However, the deutocerebrum is almost void of labeled profiles. Large numbers of nuclei are labeled in the developing embryonic visual system (Fig. 9B). Double labeling with phos $\mathrm{H} 3$ reveals that two bands of apoptotic nuclei flank the band-shaped proliferation zone of the medulla externa. This characteristic ordered distribution of TUNEL profiles in the visual system is evidence that the TUNEL assay in fact labels apoptotic nuclei (Harzsch et al., 1998). The abundant proliferating and dying cells are found in close relationship in the developing visual system, whereas the proportion of dying cells is small in the embryonic deutocerebrum under these experimental conditions.

Nevertheless, in postlarval animals, a considerable number of TUNEL profiles are found in cell cluster 10 (Fig. 9C1,D1,E1, arrows, $9 C 4, D 4, E 3$, bright-field images to demonstrate the posi- 

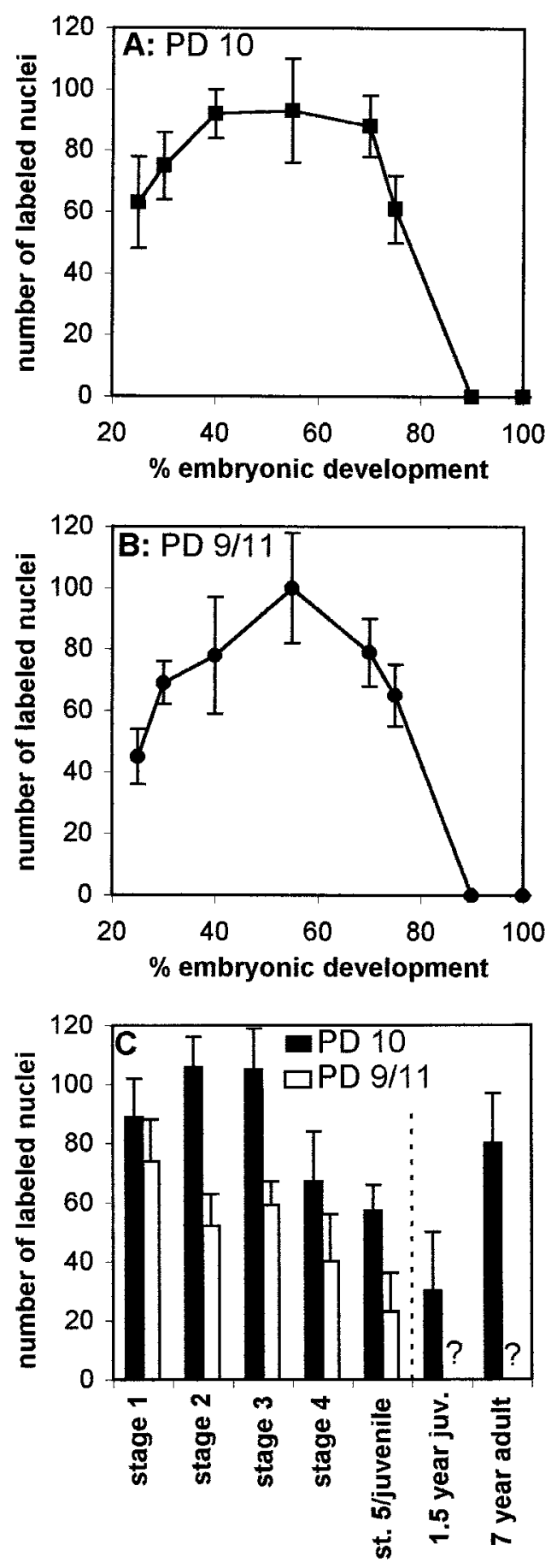

Figure 8. Quantification of nuclei labeled in a $4 \mathrm{hr}$ pulse of $\operatorname{BrdU}(A, B$, embryos; $C$, larvae and stage 5 juveniles) or two BrdU injections in $24 \mathrm{hr}$ (right bars in $C, 1.5$-year-old juvenile and adult lobsters) in PDs 10 and 9/11. Asterisks in $C$ indicate values for PD 9 not defined. $n=54$ in $A$ and $B ; n=53$ and 41 in $C$ (PDs 10 and 9/11, respectively).

tion of the labeled cells in cluster 10). Double labeling with phos $\mathrm{H} 3$ to reveal mitotic cells shows that dying cells are found close to the proliferating cells in PD 10, as well as scattered throughout cell cluster 10 (Fig. 9C2,C3). Many nuclei that are labeled by the TUNEL assay (Fig. 9C1) appear to be small and pyknotic when compared with the phos H3-labeled mitotic nuclei in prophase, metaphase, and anaphase (Fig. 9C2). Some of the TUNEL- labeled nuclei have a fragmented appearance, thus displaying a typical apoptotic morphology (Fig. 9C1,E1, insets). A closer examination using confocal laser scan microscopy revealed that, despite the scattered distribution of the TUNEL label, some of these nuclei retain morphological features that clearly identify them as neuronal nuclei and distinguish them from glial nuclei (Fig. 10A,B). The phos H3-labeled PD 10 cells in the 1.5- and 7 -year-old animals are always arranged in a small circumscribed group embedded in cell cluster 10 at the boundary near the ALs (Fig. 9D,E), thus confirming the results that were obtained by the experiments with BrdU S-phase detection. Our findings on cell death are corroborated by the analysis of toluidine blue-stained histological sections of the brain of a stage 4 animal (Fig. 11). Darkly stained pyknotic nuclei are scattered throughout cell cluster 10 and are often located in the immediate neighborhood of cells that display a regular neuronal morphology (Fig. 11A-C). Compaction of the nucleus and condensation of the chromatin are commonly regarded as the first signs of apoptosis that can be detected with the light microscope (Kerr et al., 1995). The histological sections also revealed that, in the stage 4 animals, as in the adult lobsters (Fig. $6 D, E$ ), cluster 10 is almost exclusively composed of neuronal cell bodies (Fig. 11B). Only very few of the typically spindle-shaped (Fig. 11E) or irregularly shaped (Fig. $11 D$ ) nuclei of glial cells can be detected within cell cluster 10 (Fig. 11A). However, glial cells are abundant at the cell cortexneuropil interface and along major fiber tracts (Fig. 11 $A, D, E$ ). Together, these findings and the analysis of TUNEL-labeled nuclei by confocal laser scan microscopy indicate that many of the dying cells in cluster 10 are in fact neurons.

\section{DISCUSSION}

\section{Structure of the crustacean olfactory system}

The structural organization of the adult crustacean central olfactory pathway is well known (Blaustein et al., 1988; Sandeman et al., 1992, 1995a,b; Mellon and Alones, 1993; Sandeman and Sandeman 1994; Schmidt and Ache, 1996). It consists of the paired OLs, which receive the primary sensory input, the paired ALs (multimodal integrative centers), the deutocerebral commissure, and the hemiellipsoid bodies (HEs) in the eyestalks, which are linked to the OLs via the olfactory-globular tract (OGT) (Fig. 3). Both lobes are composed of neuropil organized in discrete conical or spherical units called glomeruli. A single glomerulus of the OL represents a morphological and functional subunit containing the processes and synaptic terminals of olfactory sensory neurons, local interneurons, and projection neurons. The morphological and physiological properties of many cellular elements of the olfactory pathway have been studied (Derby and Blaustein, 1988; Schmidt and Ache, 1992, 1996; Sandeman and Sandeman, 1994; Sandeman et al., 1995a,b; Mellon and Alones, 1997; Wachowiak and Ache, 1997), as well as pharmacological aspects and the immunohistochemical localization patterns of neurotransmitters (Orona et al., 1990; Orona and Ache, 1992; Langworthy et al., 1997; Schmidt and Ache, 1997; Beltz, 1999). The cell somata of the interneurons of the central olfactory pathway are located in three cell clusters: the lateral cluster (cluster 10), which houses projection neurons, and the ventral and medial clusters (clusters 9 and 11), which contain local interneurons (Sandeman et al., 1992). The cluster 10 projection neurons possess dendritic arborizations in the AL, the OL, or in both, and their axons travel into the ipsilateral and/or contralateral $\mathrm{HE}$ via the OGT (Mellon and Alones, 1993; Sandeman and Sandeman, 1994; Schmidt and Ache, 1996; Wachowiak et al., 1996). The 

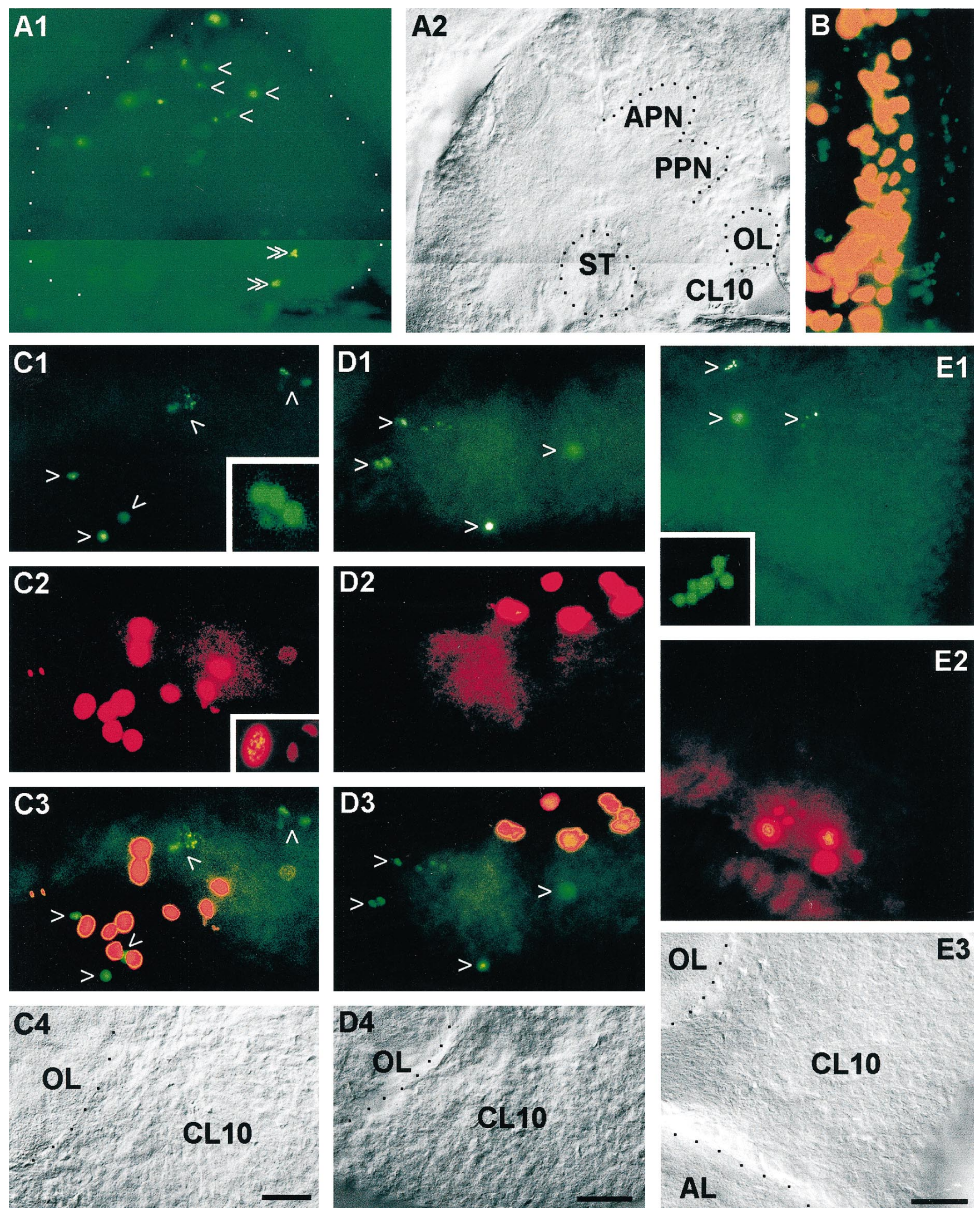

Figure 9. Coincidence of apoptotic cell death and cell proliferation in the lobster olfactory brain as demonstrated by double labeling with the TUNEL assay ( green, to label apoptotic cells) and phos $\mathrm{H} 3$ (red or orange, to label mitotic cells). A, Whole mount of a brain at E25\%, photomontage. A1, TUNEL assay, numerous nuclei are labeled in the protocerebrum (single arrowheads) but only a few in the deutocerebrum (double arrowheads). A2, same specimen under bright-field illumination. $B$, Whole mount of an eyestalk anlage at E25\%; the proliferation zone of the medulla externa (orange) is flanked by two bands of apoptotic cells (green). C, Whole mount of the olfactory lobe $(O L)$ and cell cluster $10(C L 10)$ of a stage 7 juvenile; (Figure legend continues) 

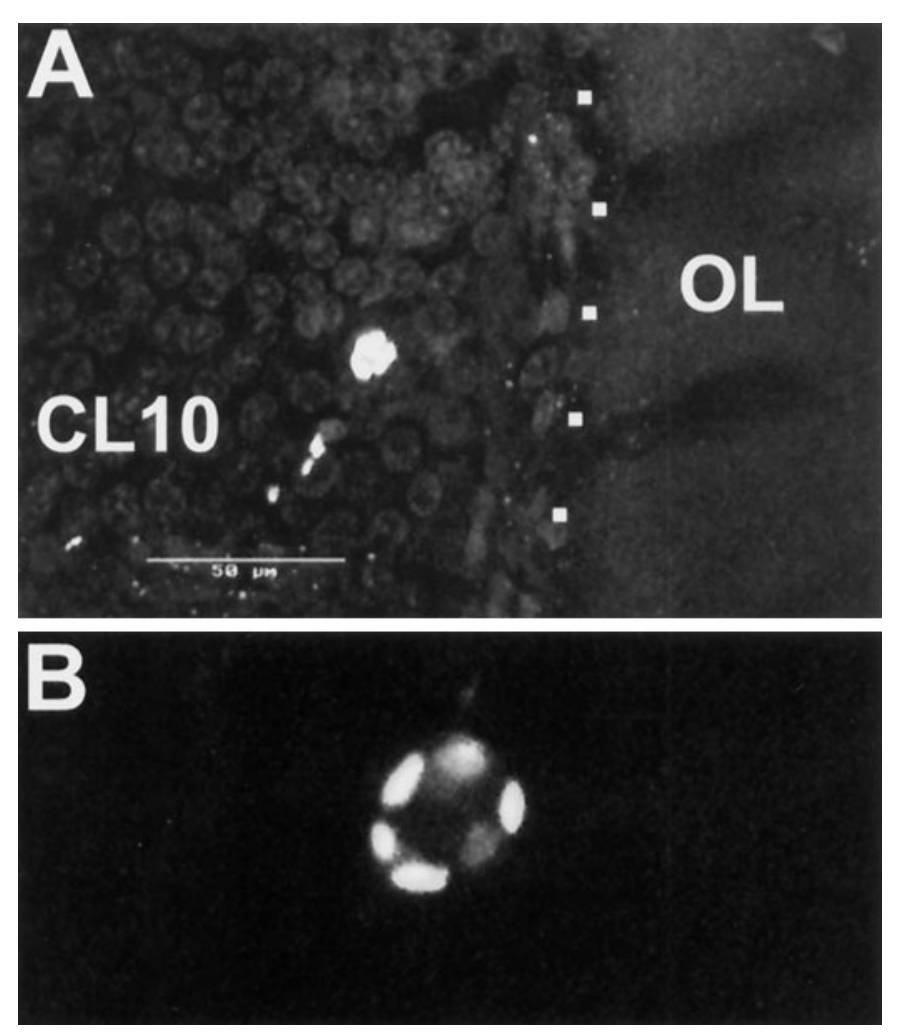

Figure 10. Apoptotic neuron in cluster 10 of a 0.5 -year-old juvenile, TUNEL assay and confocal laser scan microscopy. $A$, Composite image of 10 optical sections at $2 \mu \mathrm{m}$ intervals. Note that size and shape of the labeled nucleus resembles that of the surrounding unlabeled neurons in cluster 10. $B$, Higher magnification of the cell shown in $A$, composite of three optical sections at $2 \mu \mathrm{m}$ intervals. CL10, Cell cluster 10; OL, olfactory lobe. Scale bar, $50 \mu \mathrm{m}$.

neurites of the local interneurons in cluster 9 branch in the OL, the AL, or in both, whereas the neurites of cluster 11 neurons join the deutocerebral commissure (Mellon and Alones, 1994; Sandeman and Sandeman, 1994; Sandeman et al., 1995a; Wachowiak et al., 1996, 1997; Schmidt and Ache, 1997) (Fig. 7).

\section{Neurogenesis in the crustacean deutocerebrum}

Despite this detailed knowledge of the adult morphology, there are relatively few reports on the development of the crustacean olfactory system (Sandeman and Sandeman, 1990; Beltz et al., 1992; Helluy et al., 1993, 1995, 1996; Benton et al., 1997). Hence, although neurogenesis in the developing insect nervous system has been studied in depth (for review, see Campos-Ortega, 1993; Goodman and Doe, 1993; Burrows, 1996; Doe and Skeath, 1996; Reichert and Boyan, 1997), the present report is among the first to analyze neurogenesis in the embryonic crustacean deutocerebrum using the in vivo incorporation of BrdU. A comparison of embryonic neurogenesis in the brain versus the ventral nerve cord of the lobster (Harzsch et al., 1998) reveals that the mitotic activity of neuroblasts in both areas is high during midembryonic life but slows down toward hatching and completely ceases by E90\%. Neuronal stem cells in the ventral nerve cord do not resume their proliferative action after hatching (Harzsch et al., 1998), whereas in the deutocerebrum a distinct period of larval neurogenesis occurs. Similarly, neurogenesis has been found in the deutocerebral cell cluster 10 (olfactory projection neurons) of larval and juvenile stages of the spider crab (Harzsch and Dawirs, 1996). These results have been extended by the discovery of persistent cell proliferation in the olfactory brain of juvenile and adult shore crabs (Schmidt, 1997) and subsequently by a comparative study on adult animals of nine species of decapod crustaceans, all of which show continuous proliferation in the central olfactory pathway (Harzsch and Schmidt, 1996; Sandeman et al., 1998; Schmidt and Harzsch, 1999). The present study closes a gap in our knowledge of this phenomenon in that it provides information on the continuous cell proliferation and gradual displacement of the PD in clusters 10, 9, and 11 from early embryonic through larval and juvenile stages into adult life.

\section{Turnover of olfactory projection neurons}

By confirming that the newly born cells differentiate into mature neurons, the present study provides additional evidence that the persistent proliferation in the larval, juvenile, and adult crustacean deutocerebrum contributes new olfactory interneurons to cell cluster 10. Using BrdU-labeling experiments with a postinjection survival time of 6 weeks (pulsechase experiments), we were able to demonstrate that many of the labeled cells survive, are displaced away from the PD further toward the center of cluster 10, and attain a nuclear morphology and size that is similar to that of the surrounding mature interneurons. The nuclei of glial cells, which are by far less abundant in cluster 10 than neuronal cell bodies, display a clearly different nuclear morphology and are smaller in size than the cells detected by pulse-chase labeling. Similar results were obtained by Harzsch and Schmidt (1996) and Schmidt (1997) by pulse-chase experiments in adult crabs and crayfish. Furthermore, Schmidt (1997) found a linear increase in the number of cluster 10 neurons throughout the postlarval life of the shore crab by counts of their somata and axons in sectioned material. Together, there is strong evidence that persistent neurogenesis among olfactory interneurons is a common feature of the juvenile and adult brain of decapod crustaceans. In addition, our experiments using TUNEL indicate that apoptotic cell death takes place at the same time as cell proliferation in cluster 10 of mature brains. An examination of these apoptotic cells using confocal laser scan microscopy revealed that at least a substantial number of the dying cells are in fact neurons. Our finding that neurogenesis and neuronal cell death occur simultaneously suggests that, in addition to the increase in absolute numbers of cluster 10 cellsproposed by Schmidt

\section{$\leftarrow$}

see $C 4$ for labels. $C 1$, TUNEL assay, arrowheads point to labeled nuclei; inset, higher magnification of a TUNEL-labeled fragmented nucleus that displays a typical apoptotic morphology. $C 2$, phos $\mathrm{H} 3$, mitotic cells in PD10; inset, higher magnification of nuclei in prophase or metaphase (left) and in anaphase (right). C3, double exposure of $C 1$ and $C 2$. C4, Bright-field image of the same specimen. $D$, Vibratome section, brain of a 1.5-year-old juvenile; see $D 4$ for labels. D1, TUNEL assay, arrowheads point to labeled nuclei. D2, Phos H3, mitotic cells in PD10. D3, Double exposure of D1 and D2. D4, Bright-field image of the same specimen. E, Vibratome section, brain of a 7-year-old adult; see E3 for labels. E1, TUNEL assay, arrowheads point to labeled nuclei; inset, higher magnification of a TUNEL-labeled fragmented nucleus that displays a typical apoptotic morphology. E2, Phos H3, mitotic cells in PD10. $E 3$, Bright-field image of the same specimen. $A L$, Accessory lobe; $A P N$, anterior protocerebral neuropil; $C L 10$, cell cluster 10; $O L$, olfactory lobe; $P P N$, posterior protocerebral neuropil. Scale bars: $A-E, 50 \mu \mathrm{m}$. 

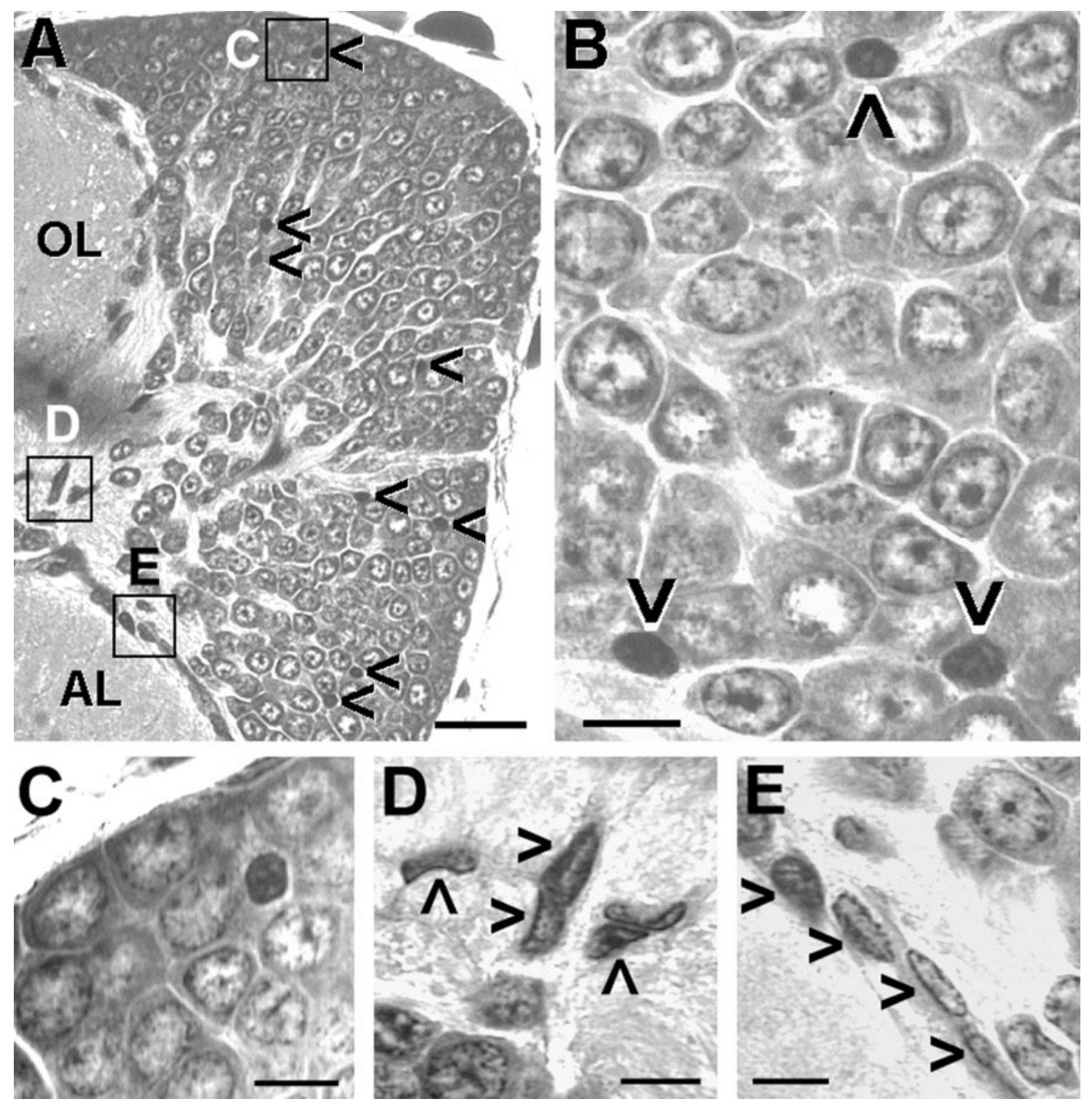

Figure 11. Cell death in the olfactory brain demonstrated by toluidine blue-stained section, stage 4 larva; $A, B$, Darkly stained pyknotic nuclei that exhibit compaction of the nucleus and condensation of the chromatin are scattered throughout cell cluster 10 (arrowheads in $A, B$ ), often near neurons that display a regular nuclear morphology $(B, C) . B, C$, Cell cluster 10 is almost exclusively composed of neuronal cell bodies. $D, E$, Very few of the typically spindle-shaped (arrowheads in $E$ ) or irregularly shaped (arrowheads in $D$ ) nuclei of glial cells can be detected within cell cluster 10, but these glial cells are abundant at the cell cortex-neuropil interface and along major fiber tracts $(A, D, E)$. Location of $C-E$ is indicated in $A$. $O L$, Olfactory lobe; $A L$, accessory lobe. Scale bars: $A, 25 \mu \mathrm{m} ; B-E, 5 \mu \mathrm{m}$.

(1997), there is likely to be a turnover of olfactory interneurons. Similar conclusions have been reached by Sandeman et al. (1998) in a study on lesion-induced plasticity in the olfactory system of the crayfish. This turnover of central neurons may well be related to the continuous turnover of olfactory receptor neurons that has been reported in the antennules of crayfish (Sandeman and Sandeman, 1996).

The number of glomeruli in the OLs of the American lobster increases progressively during embryonic and larval life to $\sim 200$ per lobe and is stable in juvenile and adult animals (Helluy et al., 1996). Despite the fact that during growth of the lobster receptor neurons are continually added in the antennules and that the new sensory axons grow into the olfactory lobes, it has been suggested that the glomerular scaffold in mature animals is stable, and neither addition nor elimination of glomeruli occurs (Helluy et al., 1996).
The idea of a turnover of olfactory receptor neurons and central projection neurons is compatible with the proposed stability of the glomerular population. The turnover does not affect the integrity of the glomeruli as a morphological unit; however, the cellular elements that contribute to the glomeruli appear to be constantly changing. Therefore, contrary to the stability that fixed glomerular numbers throughout life imply, we now suggest that the olfactory pathway of the lobster is actually composed of a slowly evolving group of neuronal elements: the sensory neurons that have long been recognized to turn over in crustaceans and the projection neuron population in cluster 10 . We hypothesize that a slow evolution in the composition of input and output neurons in the olfactory pathway could provide an anatomical substrate for the changing olfactory abilities that are observed in these animals as they mature in an ever-changing olfactory environment. 


\section{Structural neuroplasticity in arthropods and vertebrates}

To our knowledge, a turnover of central neurons, suggested by Sandeman et al. (1998) and the present study, has not been reported previously from any other invertebrate species. It is not among the known factors that shape the developing olfactory system in insects (Boeckh and Tolbert, 1993; Oland and Tolbert, 1996), although processes of structural neuroplasticity that are related to long-term environmental changes, behavioral modifications, age, and experience seem to be common in insects (Technau, 1984; Withers et al., 1993, 1995; Fahrbach et al., 1995a; Heisenberg et al., 1995; Davis and Han, 1996; Gronenberg et al., 1996; Winnington et al., 1996; Sigg et al., 1997). Neurogenesis has been found in the adult mushroom bodies of a considerable number of insect species (Bieber and Fuldner, 1979; Technau, 1984; Cayre et al., 1994, 1996), but this phenomenon is absent in other insects and therefore cannot be seen as a common feature in all insect brains (Fahrbach et al., 1995b; Gronenberg et al., 1996). The mushroom bodies are thought to be the key structures that are involved in the generation of complex behavioral patterns, the neuronal control of adaptive behavioral modifications, learning, and memory (Heisenberg, 1994; Hammer and Menzel, 1995; Strausfeld et al., 1995; Menzel and Müller, 1996). Interestingly, it has been proposed that the crustacean HEs may be homologous to the insect mushroom bodies (Strausfeld et al., 1995). Because the HEs are the target neuropils of the olfactory projection neurons in cluster 10 , it may be concluded that a turnover of cluster 10 neurons causes considerable structural plasticity in the HEs. In fact, there is evidence for a persistent neurogenic activity in a cluster of $\mathrm{HE}$ local interneurons in some crab species (Schmidt, 1997; Schmidt and Harzsch, 1999).

In vertebrates, available evidence suggests that persistent neurogenesis may be related to plasticity and learning and is an integral part of the normal biology of the mature brain (AlvarezBuylla and Temple, 1998; Cameron and McKay, 1998), the best known example being the adult hippocampus in which granule cells continue to be born throughout the life of rodents (Ray et al., 1997; Gage et al., 1998) and humans (Eriksson et al., 1998). In songbirds, widespread telencephalic adult neurogenesis adds new neurons to the high vocal center, replacing older cells that die. Neuronal turnover in the high vocal center is thought to play a role in the modification of perceptual memories or motor programs for song production in these animals (Alvarez-Buylla and Kirn, 1997; Goldman, 1998). Furthermore, in the subventricular zone of the adult mammalian forebrain, a cell population retains the potential to generate new neurons destined for the olfactory bulb (Goldman, 1997, 1998; Garcia-Verdugo et al., 1998; Luskin, 1998). Similarly, olfactory receptor neurons in the vertebrate olfactory epithelium (with targets in the olfactory bulb) undergo a continual turnover throughout life (Calof et al., 1998). If the life-long turnover of olfactory receptor cells in crustacean antennules (Sandeman and Sandeman, 1996) is linked to the persistent neurogenesis and inherent turnover of interneurons in the olfactory pathway of the adult crustacean brain suggested in the present study, a highly dynamic picture of olfaction in crustaceans emerges that contrasts with the "hard-wired" view of invertebrate olfaction that has arisen primarily from work on insects (Hildebrand, 1996). In this view, neurogenesis-induced structural neuroplasticity in crustaceans, as in vertebrates, may play a vital role in the functioning of the adult nervous system.

\section{REFERENCES}

Ajiro K, Yoda K, Utsumi K, Nishikawa Y (1996) Alteration of cell cycle-dependent histone phosphorylation by okadaic acid. J Biol Chem 271:13197-13201.

Alvarez-Buylla A, Kirn JR (1997) Birth, migration, incorporation, and death of vocal control neurons in adult songbirds. J Neurobiol 33:585-601.

Alvarez-Buylla A, Temple S (1998) Stem cells in the developing and adult nervous system. J Neurobiol 36:105-110.

Beltz BS (1999) The distribution and functional anatomy of aminecontaining neurons in decapod crustaceans. Microsc Res Tech 44:105-120.

Beltz BS, Helluy S, Ruchhoeft ML, Gammil LS (1992) Aspects of the embryology and neural development of the American lobster. J Exp Zool 261:288-297.

Ben-Sasson SA, Sherman Y, Gavrieli Y (1995) Identification of dying cells-in situ staining. In: Methods in cell biology: cell death, Vol 46 (Schwartz LM, Osborne BA, eds), pp 29-40. New York: Academic.

Benton J, Huber R, Ruchhoeft M, Helluy S, Beltz B (1997) Serotonin depletion by 5,7-dihydroxytryptamine alters deutocerebral development in the lobster, Homarus americanus. J Neurobiol 33:357-373.

Bieber M, Fuldner D (1979) Brain growth during the adult stage of a holometabolous insect. Naturwissenschaften 66:426.

Blaustein DN, Derby CD, Simmons RB, Beall AC (1988) Structure of the brain and medulla terminalis of the spiny lobster Panulirus argus and the crayfish Procambarus clarkii with an emphasis on olfactory centers. J Crustac Biol 8:493-519.

Boeckh J, Tolbert LP (1993) Synaptic organization and development of the antennal lobe in insects. Microsc Res Tech 24:260-280.

Bulloch AGM, Jones PG (1988) Modulation of neurite outgrowth by intact and axotomized neurons of Helisoma. Am Zool 28:1123-1134.

Bulloch AGM, Ridgway RL (1989) Neuronal plasticity in the adult invertebrate nervous system. J Neurobiol 20:295-311.

Burrows M (1996) The neurobiology of an insect brain. New York: Oxford UP.

Calof AL, Mumm JS, Rim PC, Shou J (1998) The neuronal stem cell of the olfactory epithelium. J Neurobiol 36:190-205.

Cameron HA, McKay R (1998) Stem cells and neurogenesis in the adult brain. Curr Opin Neurobiol 8:677-680.

Campos-Ortega JA (1993) Early neurogenesis in Drosophila melanogaster. In: The development of Drosophila melanogaster (Bate M, Martinez-Arias A, eds), pp 1091-1130. Plainview, NY: Cold Spring Harbor Laboratory.

Cayre M, Strambi C, Strambi A (1994) Neurogenesis in an adult insect brain and its hormonal control. Nature 368:57-59.

Cayre M, Strambi C, Charpin P, Augier R, Meyer MR, Edwards JS, Strambi A (1996) Neurogenesis in adult insect mushroom bodies. J Comp Neurol 371:300-310.

Charmantier G, Charmantier M, Aiken DE (1991) Metamorphosis of the lobster Homarus (Decapoda): a review. J Crustac Biol 11:481-495.

Davis RL, Han KA (1996) Mushrooming mushroom bodies. Curr Biol 6:146-148.

Derby CD, Blaustein DN (1988) Morphological and physiological characterization of individual olfactory interneurons connecting the brain and eyestalk ganglia of the crayfish. J Comp Physiol [A] 163:777-794.

Doe CQ, Skeath JB (1996) Neurogenesis in the insect central nervous system. Curr Opin Neurobiol 6:18-24.

Dohle W (1976) Die Bildung und Differenzierung des postnauplialen Keimstreifs von Diastylis rathkei (Crustacea, Cumacea). II. Die Differenzierung und Musterbildung des Ektoderms. Zoomorphologie $84: 235-277$.

Dohle W (1997) Myriapod-insect relationships as opposed to an insectcrustacean sister group relationship. In: Arthropod relationships (Fortey RA, Thomas RH, eds), pp 305-315. London: Chapman and Hall.

Dohle W, Scholtz G (1997) How far does cell lineage influence cell fate specification in crustacean embryos? Semin Cell Dev Biol 8:379-390.

Dolbeare F (1996) Bromodeoxyuridine: a diagnostic tool in biology and medicine. III. Proliferation in normal, injured and diseased tissue, growth factors, differentiation, DNA replication sites and in situ hybridization. Histochem J 28:531-575.

Eriksson PS, Perfilieva E, Björk-Eriksson, Alborn AM, Nordborg C, Peterson DA, Gage FH (1998) Neurogenesis in the adult hippocampus. Nat Med 4:1313-1317.

Fahrbach SE, Giray T, Robinson GE (1995a) Volume changes in the 
mushroom bodies of adult honey bee queens. Neurobiol Learn Mem 63:181-191.

Fahrbach SE, Strande JL, Robinson GE (1995b) Neurogenesis is absent in the brains of adult honey bees and does not explain behavioral neuroplasticity. Neurosci Lett 197:145-148.

French KA, Kristan Jr WB (1994) Cell-cell interactions that modulate neuronal development in the leech. J Neurobiol 25:640-651.

Gage FH, Kempermann G, Palmer TD, Peterson DA, Ray J (1998) Multipotent progenitor cells in the adult dentate gyrus. J Neurobiol 36:249-266.

García-Verdugo JM, Doetsch F, Wichterle H, Lim DA, Alvarez-Buylla A (1998) Architecture and cell types of the adult subventricular zone: in search of the stem cells. J Neurobiol 36:234-248.

Gerberding M (1997) Germ band formation and early neurogenesis of Leptodora kindti (Cladocera): first evidence for neuroblasts in the entomostracan crustaceans. Invertebr Reprod Dev 32:93-73.

Goldman SA (1997) Comparative strategies of subependymal neurogenesis in the adult forebrain. In: Isolation, characterization and utilization of CNS stem cells (Gage FH, Christen Y, eds), pp 43-66. Berlin: Springer.

Goldman SA (1998) Adult neurogenesis: from canaries to the clinic. J Neurobiol 36:267-286.

Goodman CS, Doe CQ (1993) Embryonic development of the Drosophila central nervous system. In: The development of Drosophila melanogaster (Bate M, Martinez-Arias A, eds), pp 1131-1207. Plainview, NY: Cold Spring Harbor Laboratory.

Gronenberg W, Heeren S, Hölldobler B (1996) Age-dependent and taskrelated morphological changes in the brain and the mushroom bodies of the ant Camponotus floridanus. J Exp Biol 199:2011-2019.

Gurley LR, D’Anna JA, Barham SS, Deaven LL, Tobey RA (1978) Histone phosphorylation and chromatin structure during mitosis in Chinese hamster cells. Eur J Biochem 84:1-15.

Hammer M, Menzel R (1995) Learning and memory in the honeybee. J Neurosci 15:1617-1630.

Harzsch S, Dawirs R (1993) On the morphology of the central nervous system in larval stages of Carcinus maenas L. (Decapoda, Brachyura). Helgol Meeresunters 47:61-79.

Harzsch S, Dawirs RR (1994) Neurogenesis in larval stages of the spider crab Hyas araneus (Decapoda, Brachyura): proliferation of neuroblasts in the ventral nerve cord. Roux's Arch Dev Biol 204:93-100.

Harzsch S, Dawirs RR (1996) Neurogenesis in the developing crab brain: postembryonic generation of neurons persists beyond metamorphosis. J Neurobiol 29:384-398.

Harzsch S, Schmidt M (1996) Brain development in adult crayfish includes the generation of new deutocerebral interneurons. Verh Dtsch Zool Ges 89:50.

Harzsch S, Anger K, Dawirs RR (1997) Immunocytochemical detection of acetylated $\alpha$-tubulin and Drosophila synapsin in the embryonic crustacean nervous system. Int J Dev Biol 41:477-484.

Harzsch S, Miller J, Benton J, Dawirs R, Beltz B (1998) Development of the thoracic neuromeres in two crustaceans with different styles of metamorphic development. J Exp Biol 210:2465-2479.

Harzsch S, Benton J, Dawirs RR, Beltz B (1999) A new look at embryonic development of the visual system in decapod crustaceans: neuropil formation, neurogenesis and apoptotic cell death. J Neurobiol 39:294-306.

Heisenberg M (1994) Central brain functions in insects: genetic studies on the mushroom bodies and central complex in Drosophila. Fortschr Zool 39:61-79.

Heisenberg M, Heusipp M, Wanke C (1995) Structural plasticity in the Drosophila brain. J Neurosci 15:1951-1960.

Helluy SM, Beltz BS (1991) Embryonic development of the American lobster (Homarus americanus): quantitative staging and characterization of an embryonic molt cycle. Biol Bull 180:355-371.

Helluy SM, Sandeman R, Beltz B (1993) Comparative brain ontogeny of the crayfish and clawed lobster-implications of direct and larval development. J Comp Neurol 335:343-354.

Helluy SM, Ruchhoeft ML, Beltz BS (1995) Development of the olfactory and accessory lobes in the American lobster: an allometric analysis and its implications for the deutocerebral structure of decapods. J Comp Neurol 357:433-445.

Helluy SM, Benton JL, Langworthy KA, Ruchhoeft ML, Beltz BS (1996) Glomerular organization in developing olfactory and accessory lobes of American lobsters: stabilization of numbers and increase in size after metamorphosis. J Neurobiol 29:459-472.
Hickmott PW, Carew TJ (1991) An autoradiographic analysis of neurogenesis in juvenile Aplysia californica. J Neurobiol 22:313-326.

Hildebrand JG (1996) Olfactory control of behavior in moths: central processing of odor information and the functional significance of olfactory glomeruli. J Comp Physiol [A] 178:5-19.

Jacobson MD, Weil M, Raff MC (1997) Programmed cell death in animal development. Cell 88:347-354.

Kerr JFR, Gobé GC, Winterford CM, Harmon BV (1995) Anatomical methods in cell death. In: Methods in cell biology: cell death, Vol 46 (Schwartz LM, Osborne BA, eds), pp 1-28. New York: Academic.

Keshishian H, Broadie K, Chiba A, Bate M (1996) The Drosophila neuromuscular junction: a model system for studying synaptic development and function. Annu Rev Neurosci 19:545-575.

Klagges BRE, Heimbeck G, Godenschwege TA, Hofbauer A, Pflugfelder GO, Reifegerste R, Reisch D, Schaupp M, Buchner S, Buchner E (1996) Invertebrate synapsins: a single gene codes for several isoforms in Drosophila. J Neurosci 16:3154-3165.

Langworthy K, Helluy S, Benton J, Beltz B (1997) Amines and peptides in the brain of the American lobster: immunocytochemical localization patterns and implications for brain function. Cell Tissue Res 288:191-206.

Levine RB, Morton DB, Restifo LL (1995) Remodeling of the insect nervous system. Curr Opin Neurobiol 5:28-35.

Luskin MB (1998) Neuroblasts of the postnatal mammalian forebrain: their phenotype and fate. J Neurobiol 36:221-233.

Macagno ER, Gao WQ, Baptista CA, Passani MB (1990) Competition or inhibition? Developmental strategies in the establishment of peripheral projections by leech neurons. J Neurobiol 21:107-119.

Marois R, Carew TJ (1990) The gastropod nervous system in metamorphosis. J Neurobiol 21:1053-1071.

Mellon DF, Alones V (1993) Cellular organization and growth-related plasticity of the crayfish olfactory midbrain. Microsc Res Tech 24:231-259.

Mellon Jr D, Alones V (1994) Identification of three classes of multiglomerular, broad-spectrum neurons in the crayfish olfactory midbrain by correlated patterns of electrical activity and dendritic arborization. J Comp Physiol 177:55-71.

Mellon Jr DF, Alones VE (1997) Response properties of higher level neurons in the central olfactory pathway of the crayfish. J Comp Physiol [A] 181:205-216.

Menzel R, Müller U (1996) Learning and memory in honeybees: from behavior to neural substrates. Annu Rev Neurosci 19:379-404.

Murphey RK (1986) The myth of the inflexible invertebrate: competition and synaptic remodelling in the development of invertebrate nervous systems. J Neurobiol 17:585-591.

Negoescu A, Lorimier P, Labat-Moleur F, Drouet C, Robert C, Guillermet C, Brambilla C, Brambilla E (1996) In situ apoptotic cell labeling by the TUNEL method: improvement and evaluation on cell preparations. J Histochem Cytochem 44:959-968.

Oland LA, Tolbert LP (1996) Multiple factors shape development of olfactory glomeruli: insights from an insect model system. J Neurobiol 30:92-109.

Orona E, Ache BW (1992) Physiological and pharmacological evidence for histamine as a neurotransmitter in the olfactory CNS of the spiny lobster. Brain Res 590:136-143.

Orona E, Battelle BA, Ache BW (1990) Immunohistochemical and biochemical evidence for the putative inhibitory neurotransmitter histamine and GABA in lobster olfactory lobes. J Comp Neurol 294:633-646.

Ray J, Palmer TD, Suhonen J, Takahashi J, Gage FH (1997) Neurogenesis in the adult brain: lessons learned from the studies of progenitor cells from the embryonic and adult nervous system. In: Isolation, characterization and utilization of CNS stem cells. (Gage FH, Christen Y, eds), pp 129-150. Springer: Berlin.

Reichert H, Boyan G (1997) Building a brain: developmental insights in insects. Trends Neurosci 20:258-263.

Sandeman D, Sandeman R, Derby C, Schmidt M (1992) Morphology of the brain of crayfish, crabs, and spiny lobsters: a common nomenclature for homologous structures. Biol Bull 183:304-326.

Sandeman D, Beltz B, Sandeman R (1995a) Crayfish brain interneurons that converge with serotonin giant cells in accessory lobe glomeruli. J Comp Neurol 352:263-279.

Sandeman DC, Sandeman RE (1994) Electrical responses and synaptic connections of giant serotonin-immunoreactive neurons in crayfish olfactory and accessory lobes. J Comp Neurol 341:130-144. 
Sandeman R, Sandeman D (1990) Development and identified neural systems in the crayfish brain. In: Frontiers in crustacean neuroscience (Kennedy K, ed), pp 498-508. Basel: Birkhäuser.

Sandeman RE, Sandeman DC (1996) Pre- and postembryonic development, growth and turnover of olfactory receptor neurones in crayfish antennules. J Exp Biol 199:2409-2418.

Sandeman RE, Watson AHD, Sandeman DC (1995b) Ultrastructure of the synaptic terminals of the dorsal giant serotonin-IR neuron and deutocerebral commissure interneurons in the accessory and olfactory lobes of the crayfish. J Comp Neurol 361:617-632.

Sandeman RE, Clarke D, Sandeman D, Manly M (1998) Growth-related and antennular amputation-induced changes in the olfactory centers of crayfish brain. J Neurosci 18:6195-6209.

Sanders EJ, Wride MA (1996) Ultrastructural identification of apoptotic nuclei using the TUNEL technique. Histochem J 28:275-281.

Schmidt M (1997) Continuous neurogenesis in the olfactory brain of adult shore crabs, Carcinus maenas. Brain Res 762:131-143.

Schmidt M, Ache BW (1992) Antennular projections to the midbrain of the spiny lobster. II. Sensory innervation of the olfactory lobe. J Comp Neurol 318:291-303.

Schmidt M, Ache BW (1996) Processing of antennular input in the brain of the spiny lobster, Panulirus argus. II. The olfactory pathway. J Comp Physiol [A] 178:605-628.

Schmidt M, Ache BW (1997) Immunocytochemical analysis of glomerular regionalization and neuronal diversity in the olfactory deutocerebrum of the spiny lobster. Cell Tissue Res 286:541-563.

Schmidt M, Harzsch S (1999) Comparative analysis of neurogenesis in the central olfactory pathway of adult decapod crustaceans by in vivo BrdU-labeling. Biol Bull, in press.

Scholtz G (1992) Cell lineage studies in the crayfish Cherax destructor (Crustacea, Decapoda): germ band formation, segmentation and early neurogenesis. Roux's Arch Dev Biol 202:36-48.

Scholtz G (1995) Head segmentation in crustacea-an immunocytochemical study. Zoology 98:104-114.

Sigg D, Thompson CM, Mercer AR (1997) Activity-dependent changes to the brain and behavior of the honey bee, Apis mellifera (L.). J Neurosci 17:7148-7156.

Strausfeld NJ, Buschbeck EK, Gomez RS (1995) The arthropod mushroom body: its functional roles, evolutionary enigmas and mistaken identities. In: The nervous system of invertebrates: an evolutionary and comparative approach (Breidbach O, Kutsch W, eds), pp 349-381. Basel: Birkhäuser.

Technau GM (1984) Fiber numbers in the mushroom bodies of adult Drosophila melanogaster depends on age, sex, and experience. J Neurogenet 1:113-126.

Technau G, Heisenberg M (1982) Neural reorganization during metamorphosis of the corpora pedunculata in Drosophila melanogaster. Nature 295:405-406.

Truman JW (1992) Developmental neuroethology of insect metamorphosis. J Neurobiol 23:1404-1422.

Wachowiak M, Ache BW (1997) Dual inhibitory pathways mediated by GABA and histaminergic interneurons in the lobster olfactory lobe. J Comp Physiol [A] 180:357-372.

Wachowiak M, Diebel CE, Ache BW (1996) Functional organization of olfactory processing in the accessory lobe of the spiny lobster. J Comp Physiol [A] 178:211-226.

Wachowiak M, Diebel CE, Ache BW (1997) Local interneurons define functionally distinct regions within lobster olfactory glomeruli. J Exp Biol 200:989-1001.

Weeks JC, Wood ER (1996) Short- and long-term modification of reflex function during learning and metamorphosis in Manduca. Biol Bull 191:62-69.

White E (1996) Life, death, and the pursuit of apoptosis. Genes Dev $10: 1-15$

Whitington P (1996) Evolution of neural development in arthropods. Semin Cell Dev Biol 7:605-614.

Winnington AP, Napper RM, Mercer AR (1996) Structural plasticity of identified glomeruli in the antennal lobes of adult worker honey bee. J Comp Neurol 365:479-490.

Withers GS, Fahrbach SE, Robinson GE (1993) Selective neuroanatomical plasticity and division of labour in the honeybee. Nature 364:238-239.

Withers GS, Fahrbach SE, Robinson GE (1995) Effects of experience and juvenile hormone on the organization of the mushroom bodies of honey bees. J Neurobiol 26:130-144.

Wolszon L (1995) Cell-cell interactions define the innervation patterns of central leech neurons during development. J Neurobiol 27:335-352. 